\title{
ANALISIS MANAJEMEN RISIKO PRODUK PEMBIAYAAN GADAI EMAS SYARIAH DI BANK BJB SYARIAH KCP SUMEDANG
}

\author{
Indri Dwi Mutiara ${ }^{1}$, Trisna Wijaya ${ }^{2}$, H Asep Saepulloh ${ }^{3}$ \\ ${ }^{1}$ Program Studi Ekonomi Syariah, Universitas Siliwangi, idmutiara@ gmail.com
${ }^{2}$ Program Studi Ekonomi Syariah, Universitas Siliwangi, trisnawijaya@ unsil.ac.id
${ }^{3}$ Program Studi Ekonomi Syariah, Universitas Siliwangi, asepsaepulloh@ unsil.ac.id
}

ABSTRACT

Bank BJB Syariah Sumedang Sub-Branch Office offers various products needed by the community such as financing products, funding products, and serviceproducts. One of the financing products available at the BJB Syariah bank Sumedang Sub-Branch Office is iB Maslahah's Gold Partner is a gold-backed qardh product in which the bank provides financing facilities to customers with goldcollateral. This study aims to determine what are the risks experienced by financing gold pawning products and how the risk management process is carried out by BJBSyariah KCP Sumedang Bank in sharia gold pawning financing products. This research is a type of qualitative research using a descriptive approach. Data obtained by interview, observation, and documentation. Data credibility test uses triangulation data credibility test. While data analysis techniques use: Data reduction, data presentation, and drawing conclusions. So based on the analysis of Sharia gold pawning financing risk at SumedangKCP BJB Bank the highest risk is Market Risk, Operational Risk, and Strategic Risk. While compliance risk, legal risk, credit risk, reputation risk and liquidity riskhave low risks.

Keywords: gold pawning, risk management

\begin{abstract}
ABSTRAK
Bank BJB Syariah Kantor Cabang Pembantu Sumedang menawarkan berbagai produk yang dibutuhkan oleh masyarakat seperti produk pembiayaan, produk pendanaan, dan produk jasa. Salah satu produk pembiayaan yang ada di bank BJB Syariah Kantor Cabang Pembantu Sumedang ialah Mitra Emas iBMaslahah adalah produk qardh dengan jaminan emas dimana bank memberikan fasilitas pembiayaan kepada nasabah dengan jaminan berupa emas.Penelitian ini bertujuan untuk menganalisis risiko-risiko yang muncul pada produk mitra emas iB Maslahah dan bagaimana pelaksanaan pengelolaan risiko. Penelitian ini menggunakan metode kualitatif dengan pendekatan deskriptif. Data dikumpulkan degan menggunakan wawancara, observasi, dan dokumentasi. Uji kredibilitas data menggunakan uji kredibitas data trianggulasi. Teknik analisis data melalui 3 tahap yaitu reduksi data, penyajian data, dan penarikan kesimpulan. Jadi berdasarkan analisis risiko pembiayaan gadai emas Syariah di Bank BJB KCP Sumedang risiko yang paling tinggi ialah Risiko Pasar, Risiko Operational, dan Risiko Srategik. Sedangkan risiko kepatuhan, risiko hukum, risikokredit, risiko reputasi dan risiko likuiditas
\end{abstract}


mempunyai risiko yang rendah.

Kata kunci: gadai emas, manajemen risiko

\section{PENDAHULUAN}

Masyarakat Indonesia sudah lama mengenal pegadaian sebagai lembaga keuangan yang menawarkan pemberian pinjaman dengan menjadikan barang sebagai jaminan. Jasa gadai syariah di beberapa lembaga keuangan syariah ini merupakan realisasi atas keinginan masyarakat yang ingin mendapatkan pelayanan gadai berdasarkan syariat Islam. Beberapa bank syariah menawarkan pembiayaan gadai emas syari'ah, dimana masyarakat bisa menjadikan emas sebagai jaminan untuk mendapatkan pinjaman uang.

Bank BJB Syariah menawarkan berbagai produk yang dibutuhkan oleh masyarakat seperti produk pembiayaan, produk pendanaan, dan produk jasa. Mitra Emas iB Maslahah adalah produk jasa yang ditawarkan bank BJBS, dimana bank memberikan pembiayaan dengan jaminan berupa emas.

Setiap pembiayaan selalu ada risiko yang mungkin tidak dapat dihindari namunbisa dikelola atau dikendalikan. Risiko dalam gadai emas itu sendiri merupakan suatu keadaan yang berpotensi menimbulkan kerugian. Berdasarkan survei awal risiko terbesar yang dihadapi bank BJB Syariah KCP Sumedang diantara lain risiko strategic, dimana bank mengalami fluktuasi laba yang tidakstabil, dikarenakan produk gadai emas di bank BJB Syariah kurang dikenal nasabah dan beberapa nasabah berpendapat bahwa lebih mudah melakukan pegadaian emas di instansi lain dengan prosedur yang lebih mudah bagi nasabah. Selain risiko strategik bank BJB Syariah KCP Sumedang juga menghadapi risiko operasional dimana karyawan melakukan kesalahan dalam penaksiran emas sehingga dapat berpengaruh terhadap nilai jaminan dan merugikan perusahaan.

Sebagai lembaga keuangan yang mengimplemantasikan syariah Islam, bank syariah harus memiliki sebuah sistem manajemen pengawasan risiko yang mampu mencegah, meminimalisir atau menghilangkan risiko kerugian financial atau kerugian lainnya dari kegiatan usaha perusahaan terutama pada pembiayaan produk gadai emas.

\section{LITERATUR REVIEW}

\section{Manajemen Risiko}

Manajemen risiko adalah "suatu bidang ilmu yang membahas tentang bagaimana menerapkan ukuran dalam memetakan berbagai permasalahan yag ada dengan menempatkan berbagai pendekatan secara komprehensif dan sistematis" (Irham Fahmi, 2011: 2). Ada juga yang memberikan definisi manajemen risiko dengan "serangkaian prosedur dan metodologi yang digunakan untuk mengidentifikasi, mengukur, memantau dan mengendalikan risiko yang timbul dari kegiatan usaha bank" (Veithzal Rivai, 2013: 63). 


\section{Jenis-jenis Risiko Perbankan}

Di bawah ini adalah jenis risiko yang dihadapi oleh perbankan (Rahmani, 2009: 157158):

1. Risiko Kredit

Risiko kredit diartikan didefinisikan sebagai " risiko yang timbul sebagaiakibat kegagalan dalam memenuhi kewajiban ketika jatuh tempo". Risiko kredit dapat bersumber dari berbagai aktivitas fungsional bank seperti perkreditan, investasi dan pembiayaan perdagangan.

2. Risiko Pasar

Risiko pasar merupakan risiko yang disebabkan oleh adanya pergerakan variable pasar dari portofolio yang dimiliki oleh bank, yang dapat merugikan bank. Risiko pasar antara lain terdapat pada aktivitas fungsional bank seperti kegiatan investasi dalam bentuk surat berharga dan pasar uang maupun penyertaan pada lembaga keuangan lainnya, penyediaan dana, kegiatanpendanaan, penerbitan surat utang, serta kegiatan pembiayaanperdagangan.

3. Risiko Operasional

Risiko operasional muncul disebabkan oleh adanya ketidak cakapan dan atau tidak berfungsinya proses internal, kesalahan manusia, kegagalan system, atau adanya problem eksternal yang mempengaruhi oprasional bank. Risiko oprasional melekat pada setiap aktivitas fungsional bank, seperti kegiatan perkreditan, investasi, oprasional dan jasa, pembiayaan perdagangan, pendanaan dan instrument utang, teknologi system informasi, dan system informasi manajemen dan pengelolaan sumber daya manusia.

4. Risiko Hukum

Risiko hukum bisa disebabkan oleh adanya kelemahan aspek yuridis. Kelemahan aspek yuridis bisa disebabkan oleh adanya tuntutan hukum, tidak adanya peraturan perundang-undangan yang mendukung, atau lemahnya perikatan seperti tidak dipenuhinya syarat sahnya kontrak dan pengikatan agunan yang tidak sempurna.

5. Risiko Likuiditas

Risiko likuiditasdikategorikan menjadi 2 yaitu :

a. Risiko Likuiditas Pasar, yaitu "risiko yang timbul karena bank tidak mampu melakukan offsetting posisi tertentu dengan harga pasar karena kondisi likuiditas pasar yang tidak memadai atau gangguan pasar". 
b. Risiko Likuiditas Pendanaan, yaitu risiko "yang timbul karena bank tidak mampu mencairkan asetnya ataumemporoleh pendanaan dari sumber dana lain".

6. Risiko Reputasi

Risiko reputasi bisa disebabkan oleh adanya pemberitaan negatif tentang kegiatan usaha bank yang mengakibatkan citra bank di mata masyarakat kurang baik.

7. Risiko Strategik

Risiko yang diantara lain disebabkan karena strategi bank yang tidak tepat, juga pengambilan keputusan bisnis yang tidak tepat atau bank yang kurang responsif terhadap perubahan eksternal.

\section{Risiko Kepatuhan}

Risiko yang di sebabkan bank tidak memenuhi atau tidak mentaati perundangundangan yang berlaku, serta prinsip-priinsip syariah yang terkandung dalam alquran, assunnah dan fatwa Dewan Syariah Nasional dalam menjalankan bisnisnya.

\section{Proses/ Tahapan Manajemen Risiko}

Ada beberapa tahapan manajemen risiko, yaitu (Imam Wahyudi dkk, 2013: 66-68) :

1. Identifikasi Risiko

Proses ini bertujuan untuk menentukan risiko apa saja yang mungkin terjadi, mengapa dan bagaimana risiko bisa terjadi.

2. Pengukuran Risiko

Setelah teridentifikasi, risiko diukur secara konsisten dan disajikan ke dalam bentuk yang mudah untuk difahami. Secara garis besar pengukuran risiko terbagi dua, yaitu mendeskripsikan dan mengkuantifikasi risiko.

3. Mitigasi Risiko

Mitigasi risiko berfungsi untuk menetralisasi, meminimalisasi atau menghilangkan dampak negatif yang muncul.

4. Monitoring Risiko

Merupakan proses pemantauan yang dilakukan bank berdasarkan tingkat risiko actual yang terjadi pada bank. Monitoring diperbankan syariah tidak hanya mencakup manajemen bank syariah, namun juga mencakup pengawasan dari Dewan Pengawas Syariah (DPS)

5. Pengendalian dan Pelaporan Risiko

Pada tahap akhir ini pengawasan atas seluruh proses dilakukan secara berkesinambungan dan terdokumentasi. 


\section{Pembiayaan}

\section{Pengertian}

Pada pasal 1 poin 25 UU No.21 tahun 2008 tentang perbankan syariah, dijelaskan pembiayaan adalah "penyediaan dana atau tagihan yang berdasarkan persetujuan atau kesempatan antara bank syariah dan/ UUSdengan pihak lain yang mewajibkan pihak yang dibiayai untuk mengembalikan uang atau tagihan tersebut setelah jangka waktu tertentu dengan imbalan atau bagi hasil".

2. Fungsi Pembiayaan

Dalam Muhammad, disebutkan bahwa fungsi pembiayaan diantaranya ; meningkatkan daya guna uang ; meningkatkan daya guna barang ; meningkatkan peredara uang ; menimbulkan kegairahan berusaha ; mendorong stabilitas ekonomi ; sebagai jembatan untuk pendapatan nasional ; sebagai alat hubungan ekonomi internasional (Muhammad, 2014 : 304308).

\section{Konsep Gadai dalam Islam}

\section{Pengertian Gadai(Rahn)}

Transaksi gadai dalam fiqh Islam disebut dengan ar-rahn, yaitu suatu jenis perjanjian untuk menahan suatu barang sebagai tanggungan utang (Zainuddin Ali, 2008 : 1). Kata Ar-rahn berasal dari bahasa arab "rahana-yarhanu-rahnan" yang berarti menetapkan sesuatu. Secara bahasa, Abu Zakariya mengartikan rahn dengan kekal dan menahan suatu barang sebagai pengikat utang. (Ahmad Roni, $2015: 1$ )

Secara istilah, banyak para cendekiawan muslim yang mendefinisikan rahn. Ulama syafiiah mendefinisikan rahn itu adalah "menjadikan suatu barang yang biasa dijual sebagai jaminan utang dipenuhi dari harganya, bila yang berutang tidak sanggup membayar utangnya"(Zainudin Ali, 2008 : 2). Menurut Syafei Antonio, rahn adalah "menahan salah satu harta milik si pemilik sebagai jaminan atas utang/ pinjaman yang diterima".(Hery Sutanto, 2013 :221).

\section{Dasar Hukum Gadai}

a. Al-Quran

Dalil naqli tentang gadai dalam alquran terdapat dalam surat Albaqarah ayat 283 berbunyi : "jika kamu dalam perjalanan (dan bermuamalah secara tidak tunai) sedang kamu tidak memperoleh seorang penulis, maka hndaklah ada barang tanggungan yang dipegang”. Syaikh Muhammad Ali Sayis dalam Zainuddin Ali berpendapat bahwa ayat tersebut merupakan petunjuk agar menerapkan prinsip kehati-hatian bila seseorang akan melakukan transaksi utang piutang dalam jangka waktu tertentu (Zainuddin Ali, $2008: 5$ ).

\section{b. As-Sunnah}

Dalil naqli yang bersumber dari assunnah tentang gadai, diantaranya hadits yang diriwayatkan oleh Muslim yang sanadnya sampai ke Aisyah r.ha yang berbunyi : "Telah meriwayatkan kepada kami Ishaq bin Ibrahim Al-Hanzhali dan Ali bin Khasyram berkata : 
keduanya mengabarkan kepada kami Isa bin Yunus bin 'Amasy dari Ibrahim dari Aswad dari Aisyah berkata : bahwasanya Rasulullah saw membeli makanan dari seorang Yahudi dengan menggadaikan baju besinya".(Zainuddin Ali, 2008 : 6)

\section{METODE PENELITIAN}

Penelitian ini menggunakan metode deskriptif dengan pendekatan kualitatif. Metode deskriptif bisa didefinisikan sebagai "suatu metode penelitian untuk menggambarkan, melukiskan atau memaparkan keadaan suatu objek secara apa adanya sesuai dengan situasi dan kondisi pada saat melakukan penelitian" (Ibrahim, 2015 : 59). Hasil data yang diperoleh dari penelitian akan dianalisis, diubah serta dipelajari lebih lanjut berdasarkan teori yang telah dipelajari, sehingga bisa memberika gambaran mengenai objek yang diteliti.

Penelitian ini menggunakan sumber data primer yang langsung didapatkan dari narasumber dan data sekunder yang bersumber dari data tertulis atau dokumentasi yang diperoleh dari Bank BJBS KCP Sumedang. Teknik pengumpulan data dalam penelitian ini menggunakan observasi, wawancara dan dokumentasi. Langkah analisis data dilakukan melalu 3 yaitu reduksi data, penyajian data dan penarikan kesimpulan (Sugiyono, $2012: 373$ ).

\section{HASIL DAN PEMBAHASAN}

1. Risiko-risiko pembiayaan Gadai Emas Syariah yang Dihadapi Bank BJB Syariah KCP Sumedang

a. Risiko Kredit

Menurut hasil survey Dalam pembiayaan gadai emas Syariah di Bank BJB Syariah KCP Sumedang bahwasanya dalam risiko kredit tidak memiliki risiko terlalu besar karena pihak Bank BJB Syariah KCP Sumedang memiliki peraturan yang ketat seperti ketika nasabah yang mengalami macet atau gagal bayar pihak bank akan memberikan peringatanSP1,SP2,SP3. Dan setelah diberikan surat peringatan ketika masihmengalami kemacetan diberikan rentan waktu 15 hari karena disertifikat gadai emas ada tanggal penjualan agunan ketika setelah 15 hari tidak ada itikad baik dari nasabah maka barang jaminan akan dilelang.

\section{b. Risiko Pasar}

Menurut hasil survey Dalam pembiayaan gadai emas Syariah di Bank BJB Syariah KCP Sumedang bahwasanya risiko pasar sangat berpengaruh karena ketika harga emas turun maka berpengaruh terhadap nilai jaminan.

Contoh kasus pada tahun 2013 emas mengalami penurunan yang sangat drastis, ditahun tersebut ketika ada nasabah yang mengalami macet kredit sehingga perusahaan mengeluarkan kebijakan lelang emas, ditahun dimana harga emas turun, tentu perusahaan mendapatkan kerugian.

Risiko pasar dipengaruhi oleh perubahan nilai kurs mata uang atau fluktuasi harga emas. 
Bank BJB Syariah KCP Sumedang harus berhati- hati dalam pembiayaan gadai emas, karena risiko pasar tidak bisa di prediksi.

\section{c. Risiko Operasional}

Berdasarkan data hasil wawancara dengan pihak bank BJB Syariah, bahwa ketika menaksir barang jaminan haruslah akurat dikarenakan dapat mempengaruhi nilai jaminan dan dapat merugikan pihakbank nya itu sendiri. Karena banyaknya emas-emas palsu yang kini beredardi masyarakat sehingga perlu ketelitian dalam menaksir namun pada saat initerbantu dengan penggunaan teknologi. Metode yang digunakan dalampengujian emas yaitu dengan metode gesek, menghitung berat jenis dan menggunakan metode scan menggunakan aplikasi berupa certieye ataubarcode scanner. Selain kesalahan dalam menaksir, karyawan juga lalai dalam menginput data. Kesalahan input merupakan kesalahan yang berisiko tinggi. Ini merupakan risiko yang sangat tinggi ketika melakukanpenginputan dengan data yang salah maka akan merugikan pihak bank.

\section{d. Risiko Hukum}

Bank BJB Syariah KCP Sumedang tidak memiliki risiko hukum dikarenakan Bank BJB Syariah sudah mengikuti peraturan hukum yang diatur oleh fatwa dari DewanSyariah Nasional Majelis Ulama Indonesia yang pertama Fatwa Dewan Syariah Nasional no 25/DSNMUI/III/2002 Tentang Rahn (gadai), yang kedua Fatwa Dewan Syariah Nasional no 26/DSNMUI/III/2002 Tentang Rahn Emas.

\section{e. Risiko Likuiditas}

Berdasarkan data hasil wawancara dengan pihak bank BJB Syariah KCP Sumedang dalam risiko likuiditas tidak memiliki risiko yang tinggi dikarenakan pihak bank aman dalam segi pemodalan.

\section{f. Risiko Reputasi}

Berdasarkan data hasil wawancara dengan pihak bank BJB Syariah KCPSumedang, tidak memiliki risiko reputasi karena bank BJB Syariah KCP Sumedang tidak mempunyai publikasi yang negatif di masyarakat.

\section{g. Risiko Strategik}

Berdasarkan data hasil wawancara dengan pihak bank BJB Syariah KCP Sumedang, dimana bank mengalami fluktuasi laba yang tidak stabil, dikarenakan produk gadai emas di bank BJB Syariah kurang dikenal nasabah dan beberapa nasabah berpendapat bahwa lebih mudah melakukanpegadaian emas di instansi lain dengan prosedur yang lebih mudah bagi nasabah. 
Tabel 1. Perkembangan Nasabah yang Melakukan Pembiayaan Gadai Emas Syariah di Bank BJB Syariah KCP Sumedang

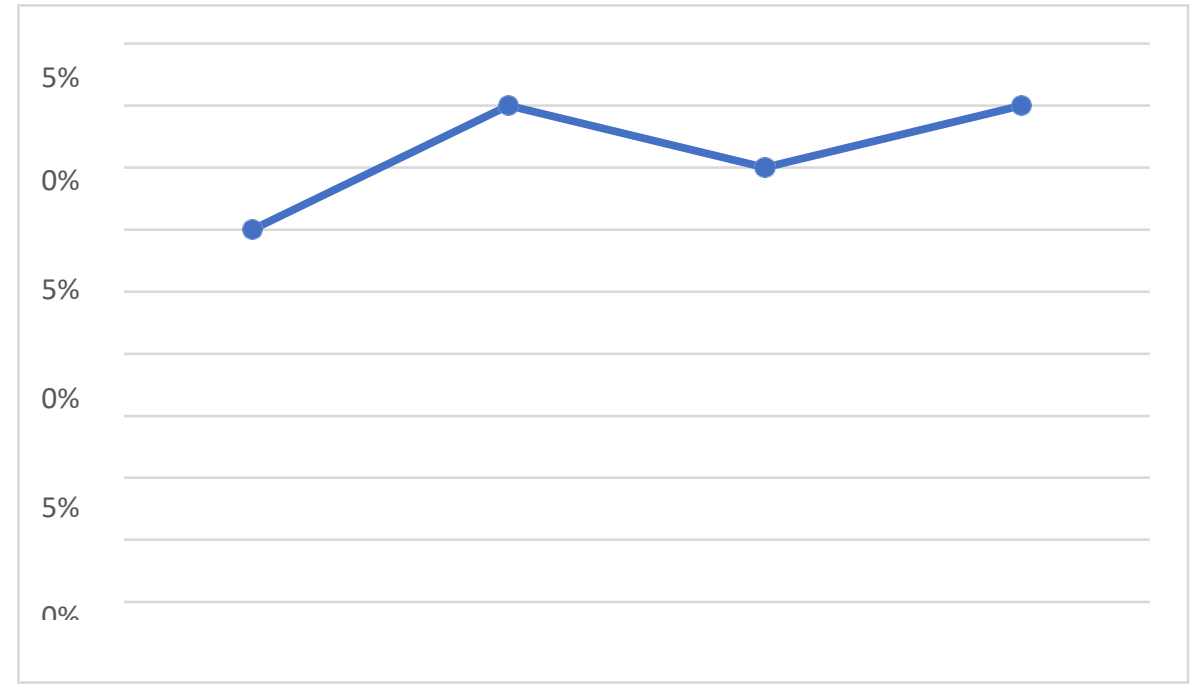

Sumber Bank BJB Syariah KCP Sumedang

Dari diagram diatas menjelaskan bahwa perkembangan nasabah dari tahun-ketahun mengalami fluktuasi yang tidak stabil, sehingga dapat mempengaruhi laba yang didapat pada pembiayaangadai emas syariah di Bank BJB Syariah KCP Sumedang.

\section{h. Risiko Kepatuhan}

Berhubungan dengan risiko kepatuhan, risiko yang dimiliki tidak terlalu tinggi karena selama ini Bank BJB Syariah selalu taat melaksanakan peraturan perundang-undangan dan ketentuan lain yang berlaku.

\section{Proses Manajemen Risiko}

Berdasarkan hasil wawancara dengan Bapak Gifar, selaku officer gadai emas syariah, ada 4 langkah proses manajemen risiko yang dilakukan Bank BJB Syariah KCP Sumedang, terkait dengan pembiayaan gadai emas syariah, yaitu :

a. Identifikasi Risiko

Dalam identifikasi risiko, pihak BJBS lebih fokus pada tiga sumber risiko, yaitu risiko operasional, risiko pasar dan risiko strategik. Ketiga risiko tersebut bersumber pada emas yang menjadi barang jaminan.

Pada risiko operasional, pihak bank membaginya menjadi beberapa tahap, yaitu : 1) uji fisik dengan ditimbang dan dilihat warnanya, 2) uji kimia dengan cara menggosokkan emas pada batu kemudian hasil gosokannya diberikan cairan kimia $\mathrm{HCL}$ dan $\mathrm{HRO}_{3}$,3) uji berat jenis dengan cara menimbang emas, jika emas tersebut tidak berongga maka akan muncul jumlah karatase. 
Pada risiko pasar, bisa dilakukan dengan cara melihat fluktuasi harga pasaran emas. Sedangkan identifikasi risiko strategic dilakukan dengan cara melihat perkembangan jumah nasabah pada setiap tahunnya.

b. Pengukuran Risiko

Untuk mengukur besar atau kecilnya risiko dalam pembiayaan gadai emas syarah, pihak bank menggunakan teori kelayakan usaha untuk mengetahui tingkat keuntungan dan kerugian dalam aktivitas bisnis, termasuk dalam mekanisme operasional gadai/rahn emas.

c. Pemantauan Risiko

Pemantauan risiko di BJBS KCP Sumedang dilakukan dengan melakukan pengecekan ke sistem komputer. Secara otomatis akan muncul nama nasabah yang bermasalah. Kemudian nasabah yang bermasalah akan dihubungi oleh pihak satu hari sebelum jatuh tempo. Apabila nasabah tidak merespon sampai satu hari setelah jatuh tempo, maka pihak bank akan mengeluarkan surat peringatan satu. Jika masih tidak ada respon bank akan memberikan surat peringatan sampai surat peringatan ke 3. Jika masih tidak ada respon dari nasabah, maka bank akan mengeksekusi barang jaminan.

Pada pemantauan risiko pasar, pihak bank akan melihat pergerakan portofolio pasar, karena pergerakan pasar berpengaruh terhadap nilai jaminan. Untuk pemantauan risiko strategic, pihak bank melakukan pemantauan dengan cara melihat jumlah nasabah yang mengajukan pembiayaan gadai emas syariah.

\section{d. Pengendalian Risiko}

Pengendalian risiko dilakukan dengan 3 cara, yaitu :

\section{1) Risk Avoidance}

Langkah ini dipilih jika bank tidak memiliki risiko yang bisa dihindari tanpa adanya pengaruh negatif terhadap pencapaian tujuan bank. Berdasarkan informasi dari petugas gadai emas, risiko utama terdapat pada barang jaminan. Oleh karena itu ketelitian dalam penaksiran jaminan menjadi sesuatu krusial dalam transaksi gadai. Penghindaran risiko pasar dilakukan dengan cara melihat harga emas secara di pasaran secara rutin, karena harga emas berubah setiap harinya.

\section{2) Risk Transfer}

Risk transfer yaitu pengalihan risiko kepada pihak atau lembaga yang ahli da cakap dalam pengendalian risiko. Bank BJBS memilih perusahaan asuransi sebagai lembaga yang dipercaya untuk mengelola risiko yang terdapat dalam produk pembiayaan gadai emas syariah.

\section{3) Risk Control}

Ketika ada pembiayaan bermasalah, dimana nasabah tidak mampu membayar kewajibannya, Bank BJBS memiliki mekanisme yang efektif dalam rangka pengendalian risiko, yaitu dengan melelang barang jaminan sebagai langkah terakhir jika nasabah mengalami gagal bayar. Jika nilai lelang lebih besar daripada kewajiban nasabah, maka sisanya menjadi hak nasabah. Hal ini sesuai dengan fatwa DSN-MUI No. 25 tahun 2002 tentang rahn. 


\section{4) Mitigasi Risiko}

Pembiayaan gadai emas merupakan produk pembiayaan yang terbilang mudah da cepat dalam proses pencairan pinjaman. Oleh karena itu pihak bank harus teliti dan hati-hati sebelum pencairan pinjaman. Bank BJB Syariah KCP Sumedang juga melakukan upaya sesudah dan sebelum menerima barang jaminan guna mengurangi resiko. Berdasarkan hasil wawancara dengan Bapak Gifar sebagai officer gadai emas syariah, pihak Bank akan melakuka proses penaksiran barang jaminan sebelum menerima barang jaminan. Penaksiran barang jaminan dilakukan dengan cara :

a. Uji fisik, yaitu pihak bank mengamati kondisi barang yang akan dijadikan jaminan.

b. Uji kimia, yaitu memeriksa kadar karat emas dengan cara menggosokan emas pada permukaan batu uji, kemudian hasil gosokannya diberikan cairan kimia $\mathrm{HCL}$ dan $\mathrm{HRO}_{3}$.

c. Uji berat jenis. Uji ini dilakukan untuk jenis emas yang padat dan tidak berongga seperti emas batangan.

\section{SIMPULAN}

Berdasarkan hasil penelitian dan pembahasan bisa diambil kesimpulan, bahwa risiko yang paling krusial pada pembiayaan gadai emas syariah terdapat pada risiko pasar, risiko operasional dan risiko strategic. Sedangkan risiko kepatuhan, risiko hukum, risiko reputasi dan risiko likuiditas memiliki tingkat risiko yang rendah. Proses manajemen risiko dilakukan dengan beberapa tahap yaitu identifikasi risiko, pengukuran risiko, pemantauan risiko dan pengendalian risiko.

\section{REFERENSI}

Ali, Zainuddin. 2008. Hukum Gadai Syariah. Jakarta : Sinar Grafika

Fahmi, Irham. 2011. Manajemen Risiko. Bandung : Alfabeta

Muhammad. 2014. Manajemen Dana Bank Syariah. Jakarta : Rajawali Pers

Rifai, Veithzal, dkk. 2013. Islamic Risk Management For Islamic Bank. Jakarta : Gramedia Pustaka Utama.

Roni, Ahmad. 2015. Asuransi dan Pegadaian Syariah. Jakarta : Mitra Wacana Media.

Sugiyono. 2012. Metode Penelitian Pendidikan Pendekatan Kuantitatif Kualitatif dan R\&D. Bandung : Alfabeta

Sutanto, Hery dan Khaerul Umam. 2013. Manajemen Pemasaran Bank Syariah. Bandung : Pustaka Setia.

Wahyudi, Imam. 2013. Manajemen Risiko Bank Islam. Jakarta : Salemba Empat.

Yulianti, Rahmani Timorita. 2009. Manajemen Risiko Perbankan Syariah. Jurnal Ekonomi Islam Vol III No 2 . 